\title{
Integrating WaTEM/SEDEM model and GIS-based FAHP Method for Identifying Ecological Rainwater Harvesting Sites in Ziz upper watershed, SE Morocco
}

Mohamed Manaouch ( $\square$ mohamed.manaouch@uit.ac.ma)

Universite Ibn Tofail Kenitra https://orcid.org/0000-0002-2362-7098

Sadiki Mohamed

Ibn Tofail University: Universite Ibn Tofail

Fenjiro Imad

Ibn Tofail University: Universite Ibn Tofail

\section{Research Article}

Keywords: RWH, WaTEM/SEDEM, GIS, FAHP, Ziz, SE Morocco

Posted Date: May 24th, 2021

DOl: https://doi.org/10.21203/rs.3.rs-529521/v1

License: (c) (i) This work is licensed under a Creative Commons Attribution 4.0 International License.

Read Full License 


\title{
Integrating WaTEM/SEDEM model and GIS-based FAHP Method for Identifying Ecological Rainwater Harvesting Sites in Ziz upper watershed, SE Morocco
}

Manaouch Mohamed ${ }^{\mathrm{a}^{*}}$, Sadiki Mohamed ${ }^{\mathrm{b}}$ and Fenjiro $\operatorname{Imad}^{\mathrm{a}}$

aLaboratory of Environment, Societies and Territories, Department of Geography, Faculty of Letters and Humanities Sciences, Ibn Tofail University, Kenitra, Morocco

${ }^{\mathrm{b}}$ Laboratory of Geo-Sciences, Department of Geology, Faculty of Sciences, Ibn Tofail University, Kenitra, Morocco

Corresponding author: Tel.: (+212) 672561079 Fax: (+212) 672561079

E-mail:mmanaouch@gmail.com

https://orcid.org/0000-0002-2362-7098

\begin{abstract}
Moroccan southeast areas have limited water ressources, vulnerable to climate change and characterized by a significant spatio-temporal variability. In response, to ensure the availability of water for local comunity, it is advised to develop some alternatives that improve the local water resources management throughout these areas. Rainwater harvesting (RWH) has been used widely as an alternative technique towards water scaricity. However, taking into account socio-economic constraints for identifying ecological sites for RWH remains a complex task for water managers. The present study was conducted using WaTEM/SEDEM model, GIS techniques and Fuzzy Analytical Hierarchy Process (FAHP) method to identify important ecological RWH sites. For this purpose, several data sources were employed to generate needful thematic layers. The soil conservation service curve number (SCS-CN) method was utilized for preparing a yearly runoff potential map. Then, the thematic layers were weighted for generating RWH suitability map. The results show that yearly surface runoff ranges from 136 to $500 \mathrm{~mm}$. Moreover, the spatial distribution map of soil erosion of WaTEM/SEDEM shows that Ziz upper watershed can be classed into four classes: (i) slight (very suitable), (ii) moderate (suitable), (iii) high (less suitable) and (iv) severe (not suitable). Aproximatly $76.1 \%$ of the study area falls within slight soil erosion class. The GIS tools were used for generating the important ecological RWH suitability map. The GIS's intersect tool was used to eliminate insuitable soil erosion classes and the buffer tool was used for integrating the socio-economic factors including the distance from residential areas and agriculltural fields . Prediction accuracy of the resultant map of RWH suitability showed the value of the area under the curve (AUC) equal to $59.6 \%$ for FAHP method in this study. Ecological RWH map, mainly, introduced western areas and some central parts of Ziz upper watershed as suitable RWH areas. The present study demonstrated that coupling WaTEM/SEDEM model with FAHP method and GIS tools provide a valuable approach for identifying the ecological RWH sites in large semi-arid areas.
\end{abstract}

Keywords :RWH. WaTEM/SEDEM. GIS. FAHP. Ziz. SE Morocco.

\section{Introduction}

The FAO organization reported that the world's request for water is rising two times as fast as the population (FAO 2015). The water need has significantly increased due to the exponential increase in the human 
population in recent decades. However, the country's available water resources are under increasing population pressure, accelerated urbanization, the increase of industrial activities and irrigated agriculture, resulting in water scarcity and food security problems. By 2025, two-thirds of the world's population will experience water stress, while around 1.8 billion people are expected to experience water scarcity. (United Nations 2014). Water resources managers around the world are therefore facing complex challenges of finding immediate change and a sustainable water management system.

In the last decades, the Moroccan government has adopted the policy of building dams. The number of dams is the most important in North African countries. However, water scarcity has become increasingly alarming as dams are unable, largely due to loss of rainwater through evapotranspiration. During dry periods, water availability is limited due to low water storage capacities, even in areas with high rainfall and low evapotranspiration.

Moroccan south-eastern areas are constantly affected by water scarcity problems. The population especially the farmers are faced with major challenges due to the succession of dry and rainy periods leading to situations of climatic uncertainty and aridity. Thus, water stress in these areas can be alleviated by collecting runoff during rainy periods, and this harvested water can be worn for domestic uses and other activities during drought periods (Rejani et al. 2017).

According to Mekdaschi and Liniger 2013 RWH consists on collecting and managing rainwater runoff to enlarge water availability for domestic and agricultural use as well as ecosystem sustenance and other researchers reported that RWH is really precious, especially in dry areas, to address water shortage, mitigate groundwater extraction, expand crop yields, increase growth and development of pastures, fight erosion, and maintain water resources (Kaposztasova et al. 2014).

Nevertheless, many studies showed that identifying potential RWH sites is a significant stage towards water security and land yield in semi-arid areas (Isioye et al. 2012). According to previous studies, especially in semi-arid areas the most influencing factors in RWH site selection are hydrologic, climatic, agronomic, topographic, soil, and socioeconomic conditions (FAO 2003).

Consequently, several criteria were employed using different techniques and/or methodologies for siting suitable RWH sites are available (Mahmoud and Alazba 2014; Ahmad 2013; Al-Adamat 2008; de Winnaar et al. 2007). Also, in other studies the optimal RWH sites were identified by taking into account many factors including socio-economical and physical aspects of a studied area (Al-Adamat et al. 2010).

Besides the key parameters for siting potential RWH sites, runoff is one the most significant (Rejani et al. 2017; Adham et al. 2016). For simulating rainfall and runoff in the present study, The Soil Conservation Service curve number (SCS-CN) method was used. The SCS-CN method is one of the most used due to its simplicity and little data requirement (de Winnaar et al. 2007). In many studies, the spatial estimates of runoff from the SCS-CN model directly have been adopted for implementing the potential sites for RWH precisely (Rejani et al. 2017; Ajaykumar et al. 2012; Pandey and Sahu 2002; Napoli et al. 2014).

Nevertheless, in areas with high surface runoff, the soil productivity can be decreased by the soil loss and its nutrients, and can then conduct to the decline of water quality by deposing soil particles in watercourses and reservoirs. Consequently, in the riskiest areas of soil erosion, runoff's reduction can increase the ecosystem's capacity to store rainwater instead of releasing surface runoff.

Nowadays, Geographic Information System (GIS) plays an important role for identifying suitable RWH sites, through which several geospatial data can be displayed, processed and analyzed. Consequently, GISbased Multi-Criteria Decision Analysis (MCDA) techniques are very important and valuable approaches to 
manage enormous spatial and non-spatial data into intended knowledge that along with subjective judgments of decision makers in some critical decisions (Chen et al. 2010).

We therefore assessed the spatial distribution of soil erosion by the WaTEM / SEDEM model and we used geographic information system software (ArcGIS 10.5) to analyze, process and overlay the spatial data and their attributes for slope, LULC, soil type and the soil erosion map to identify optimal sites for harvesting water.

Ziz upper watershed was selected as a typical semi-arid region in southeastern Morocco, to check out potential RWH sites. This area has had periodical water shortages due to dried seasons, particularly with the increase in population and the increasing demand for water from farmers. Then, water neediness has faltered as a major factor restricting local sustainable development, and big amounts of rainwater drain straight without being used or stored.

\section{Materials and methods}

\subsection{Study area}

Ziz upper watershed is one of the Moroccan southeast regions which is bordered by upper Moulouya on the north, Ghris watershed and Tafilalet plain on the south, Central High Atlas on the west and Guir basin on the east. Administratively, this area consists of one urban commune and some rural communes. The administrative center of this area is Rich center located between two cities Errachidia and Midelt. Ziz upper watershed is bounded by latitude $32^{\circ} 05^{\prime} 48$ " - $32^{\circ} 64$ ' 19 " $\mathrm{N}$ and longitude $04^{\circ} 11^{\prime} 72$ "- $05^{\circ} 46^{\prime} 20^{\prime \prime} \mathrm{W}$, covering a total area of $4435 \mathrm{~km} 2$ (Fig. 1). The study area's altitudes range from 1023 to $3386 \mathrm{~m}$ asl. and it experiences a semi-arid climate, characterized by a harsh winter and a moderate summer with hot temperatures varying depending on the altitude. The average minimum and maximum temperature of $\mathrm{Ziz}$ upper watershed are $10.2{ }^{\circ} \mathrm{C}$ and $19.2{ }^{\circ} \mathrm{C}$, respectively. The rainfall is characterized by the existence of two rainy seasons, autumn and spring, winter is less rainy and summer is dry. Average annual rainfall ranges from 119 to $377 \mathrm{~mm} \mathrm{yr}^{-1}$ (Manaouch et al. 2020). Land use/land cover (LULCs) types of the study area are classified into five major classes such as agricultural fields, very degraded forest, rangelands, settlement and water bodies with rangelands and degraded forest types have higher proportions. 


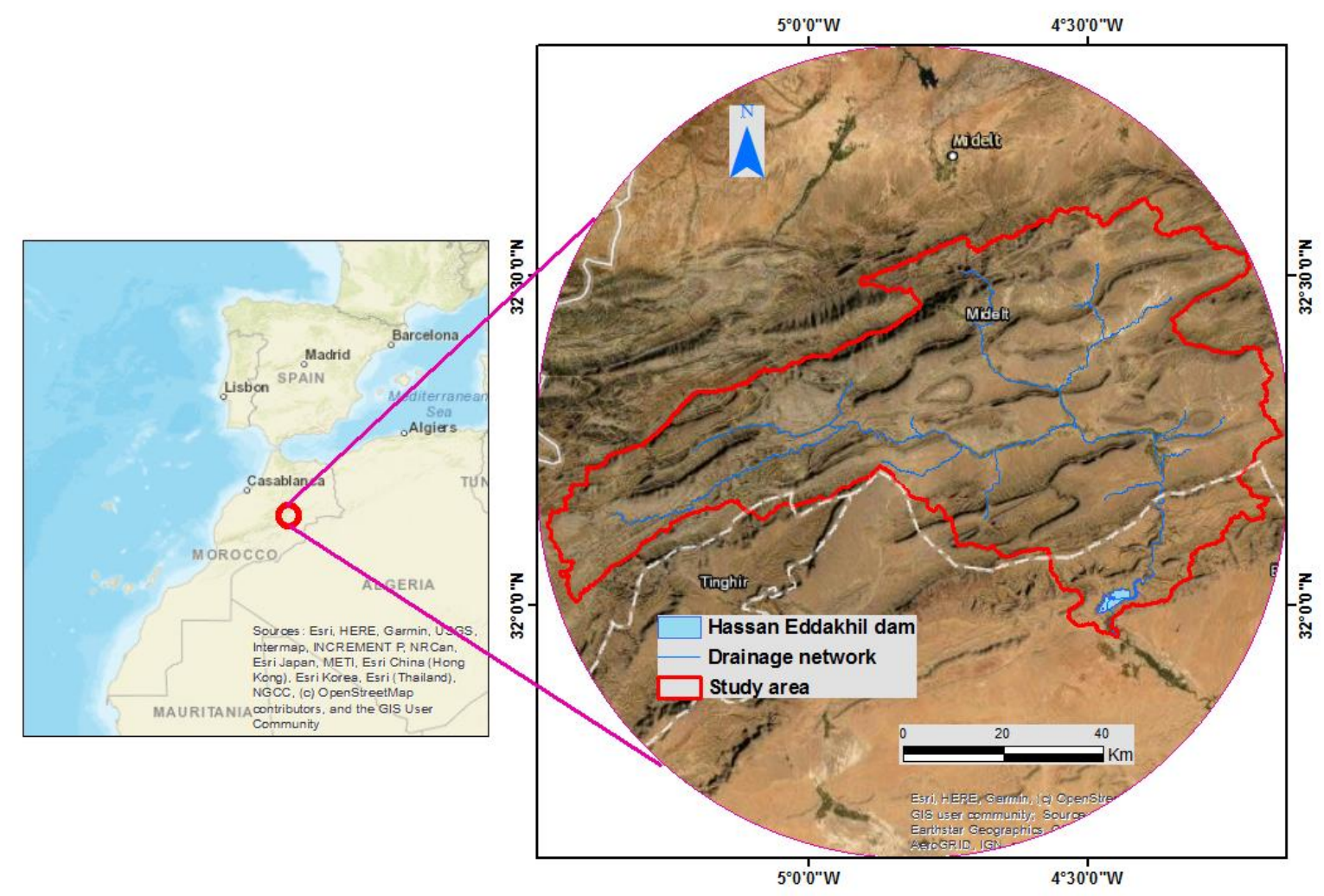

Figure 1. Location map of the study area.

\subsection{Methodology, data processing and thematic layers}

For conducting the present study, the FAHP method and the spatial distribution map of soil erosion risk were integrated in GIS environment. The first stage was the preparation of thematic layers including five criteria such as runoff, slope, hydrologic soil group, drainage density and LULC. For estimating the potential runoff map, SCS-CN model was used. For weighting and integrating all the thematic layers, the AHP method and GIS tools were employed by comparing each factor to each other's as a couple according to the expert's judgment. Then, all these layers were transformed into raster maps using fuzzy set theory. For generating the ecological RWH suitability map, the potential RWH map was overlaid with the spatial distribution of soil erosion produced by WaTEM/SEDEM model (Fig. 2). The last stage was the integration of socio-economic factors. Then, the resulted map was validated using a group of current RWH strictures. 


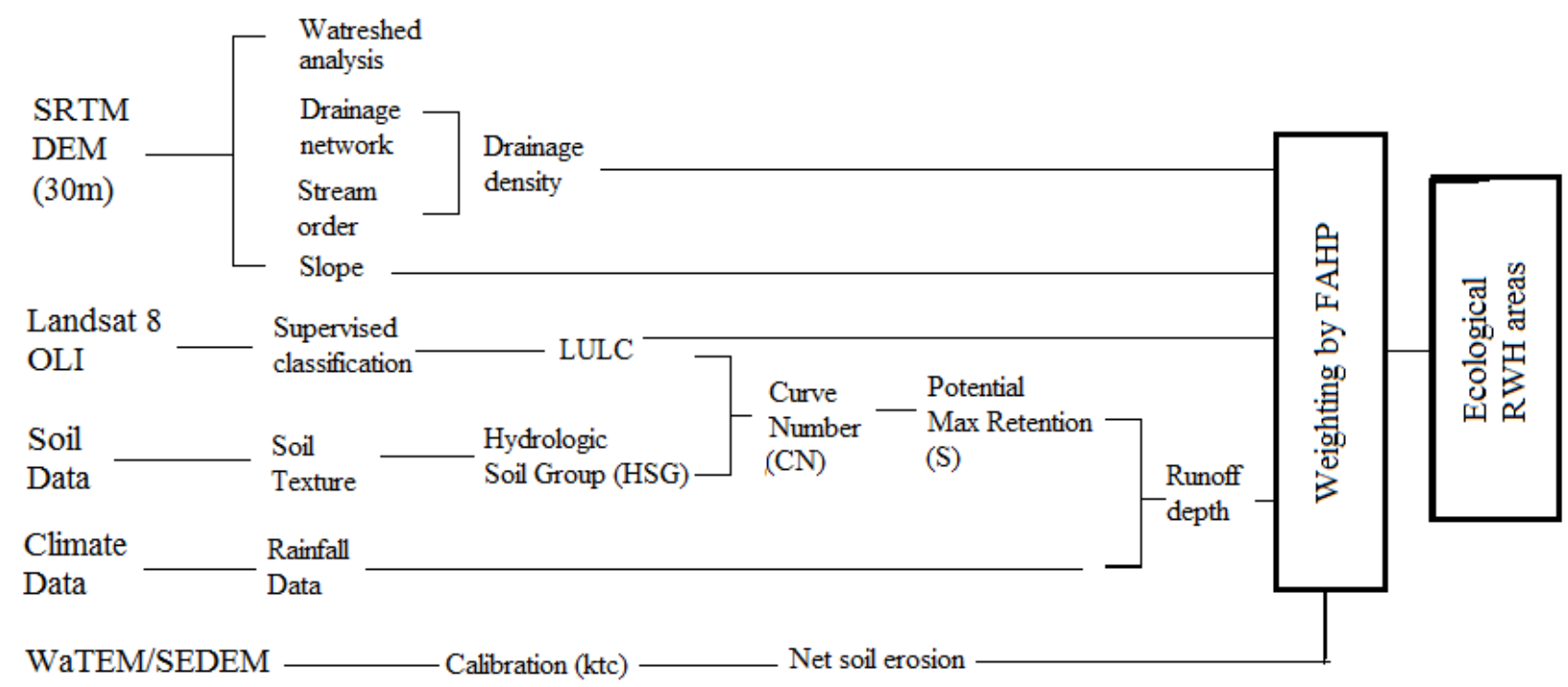

Figure 2: Flow chart showing the adopted methodology for ecological rainwater harvesting sites.

\subsubsection{Climatic data.}

In the present study, Climatic data were derived from the hydrologic watershed agency of Ziz (ABH-GZR 2020). Rainfall data from four meteorological stations in or near the study area were collected and transformed from monthly averages to yearly averages, and data for surface runoff were organized in the same way. Geographic coordinates for the meteorological stations are displayed in Table 1. Accordingly, The rainfall map was developed by using the interpolation method IDW (Inverse Distance Weighted), which allow to estimate the rainfall value of any point. Precipitation is between 128 and $443 \mathrm{~mm}$. year-1. The southern and eastern parts are the least watered. However, the western parts are experiencing high values. The wettest areas are in the western parts, representing the mountains upstream borders of the studied area (Fig. 3A).

Table 1 Geographical coordinates for the four meteorological stations.

\begin{tabular}{|l|l|l|l|l|}
\hline Station & Latitude dd $(\mathrm{N})$ & Longitude dd $(\mathrm{W})$ & $\mathrm{Z}(\mathrm{m})$ & Survey period \\
\hline Tamagourt & 32.25 & 4.73 & 1512 & $1970-2019$ \\
\hline Er-Rachidia & 31.92 & 4.42 & 1023 & $1973-2018$ \\
\hline Tillicht & 32.31 & 4.54 & 1368 & $1975-2018$ \\
\hline Imilchil & 32.15 & 5.63 & 2160 & $1999-2009$ \\
\hline
\end{tabular}

\subsubsection{Slope}

Slope is one main factor that influence the harvesting water. For this study, the slope data were extracted from the SRTM-DEM with a resolution of $30 \mathrm{~m}$. A slope map was produced using the slope tool of ArcGIS 10.5. Gentle slope's areas $\left(0-5^{\circ}\right)$ in the Ziz upper watershed represent $26.8 \%$ of the total study area, areas with slopes between $5-15^{\circ}$ represent $36.4 \%$ and areas with between 15 and $25^{\circ}$ then greater than $25^{\circ}$ respectively represent 20.3 and $16.8 \%$ (Fig. 3B). About $62 \%$ of the study area had slopes $<15^{\circ}$.

Table 2. Slope suitability class and coverage 


\begin{tabular}{|l|l|l|l|l|}
\hline Factor & Class & Rate & Classification & Coverage $(\%)$ \\
\hline \multirow{5}{*}{ Slope $\left(^{\circ}\right)$} & $\geq 25$ & 1 & Unsuitable & $16.8 \%$ \\
\cline { 2 - 5 } & $15-25$ & 2 & Less Suitable & 20.3 \\
\cline { 2 - 5 } & $5-15$ & 3 & Suitable & 36.4 \\
\cline { 2 - 5 } & $0-5$ & 4 & Very suitable & 26.38 \\
\hline
\end{tabular}

\subsubsection{Land use/ land cover (LULC)}

The LULC of a watershed has a major effect on runoff and is also an important criterion for identifying suitable sites for rainwater harvesting. LULC data were extracted by processing a satellite imagery of Landsat 8 OLI acquired in February 2021 (Mohamed et al. 2020). LULC map was classed into 4 categories based on the supervised classification in ArcGIS 10.5 (Fig. 3F). The main part of the area included rangeland followed by degraded forest (Table 3). These areas were inspected as suitable sites for potential RWH.

Table 3. LULC suitability class and coverage

\begin{tabular}{|l|l|l|l|l|}
\hline Factor & Type & Rate & Classification & Coverage (\%) \\
\hline \multirow{4}{*}{ LULC } & Agricultural field & 1 & Unsuitable & 10.1 \\
\cline { 2 - 5 } & Water bodies & 2 & Less suitable & 0.6 \\
\cline { 2 - 5 } & Degraded forest & 3 & Suitable & 25.1 \\
\cline { 2 - 5 } & Rangeland & 4 & Very suitable & 64.2 \\
\hline
\end{tabular}

\subsubsection{Soil texture and Hydrological Soil Groups (HSGs)}

Soil properties have an important impact on surface runoff by influencing infiltration rate. Data for soil texture were acquired from the prior studies, which is compiled by Manaouch et al. 2020. Soil group was reclassified from the United States Department of Agriculture - Hydrologic Soil Group (USDA 2009) (USDA- HSG) (Fig. 3C), represented by categories A to D, for treatment in the SCS-CN model. HSG-A is for high permeability with low runoff potential, accounts $0 \%$ in the Ziz upper watershed, HSG-D represents soil with high runoff potential, accounts $8.5 \%$ of the study area and HSG-B and -C are middle classes, account 73 and $18.5 \%$, respectively.

Table 4. HSGs suitability class and coverage

\begin{tabular}{|l|l|l|l|l|}
\hline Factor & Class & Rate & Classification & Coverage (\%) \\
\hline \multirow{4}{*}{ HSG } & A & 1 & Unsuitable & 0 \\
\cline { 2 - 5 } & B & 2 & Less suitable & 73 \\
\cline { 2 - 5 } & C & 3 & Suitable & 18.5 \\
\cline { 2 - 5 } & D & 4 & Very suitable & 8.5 \\
\hline
\end{tabular}

\subsubsection{Drainage density}

The drainage density parameter is computed using the total stream length per unit catchment area (Horton 1945). It is calculated as:

$$
D d=\frac{\sum_{i=1}^{n} l}{A}
$$

Where $\mathrm{Dd}$ is the drainage density, $\mathrm{n}$ is the number of streams, $\mathrm{l}$ is the stream length $(\mathrm{km})$, and $\mathrm{A}$ is the drainage area $\left(\mathrm{km}^{2}\right)$. 
The drainage density was generated from DEM using the ArcGIS 10.5 software. The drainage density map was done based on the length of streams presents in each sub-watershed. An area with high Dd was considered more suitable for RWH structures compared to other areas with low Dd (Fig. 3E). (Prinz et al. 1998)

Table 5. Drainage density suitability class and coverage

\begin{tabular}{|l|l|l|l|l|}
\hline Factor & Drainage density class & Rate & Classification & Coverage (\%) \\
\hline \multirow{2}{*}{$\begin{array}{l}\text { Drainage } \\
\text { density } \\
\left(\mathrm{km} / \mathrm{km}^{2}\right)\end{array}$} & $0-0.02$ & 1 & Unsuitable & 73.5 \\
\cline { 2 - 5 } & $0.02-0.06$ & 2 & Less suitable & 18.1 \\
\cline { 2 - 5 } & $0.06-0.12$ & 3 & Suitable & 7 \\
\cline { 2 - 5 } & $0.12-0.24$ & 4 & Very suitable & 1.4 \\
\hline
\end{tabular}

\subsection{Runoff map by SCS-CN model}

The SCS-CN model, developed by the US Soil Conservation Service in 1972, has been extensively used for assessing runoff and managing water resources due to its simplicity (SCS 1972; He 2003). In this method, some properties such as soil characteristics, LULC, topography and antecedent soil moisture conditions, are taken into consideration (Luxon and Pius 2013). Recently, the SCS-CN method has been developed for application to larger areas by weighting CNs based on the LULC of the studied area (Ramakrishnan et al. 2008). The SCS-CN model was designed for any form of LULC and soil shape, and the use of, and the use of GIS tools have facilitated the runoff prediction more accurately. The runoff estimation using ArcGIS tools is described in details on the methodology flowchart above. The SCS-CN model calculates:

$$
\begin{gathered}
Q= \begin{cases}\frac{(P-\lambda S)^{2}}{P+(1-\lambda) S} & (P<S) \\
Q=0 & (P>\lambda S)\end{cases} \\
S=\frac{25400}{C N}-254
\end{gathered}
$$

Where $\mathrm{Q}$ is the runoff depth $(\mathrm{mm}), \mathrm{P}$ is the total rainfall $(\mathrm{mm}), \mathrm{S}$ is the potential maximum retention after the beginning of runoff $(\mathrm{mm}), \lambda$ is surface runoff abstraction (dimensionless) and $\mathrm{CN}$ is the curve number that ranges from 0 to 100 , reflecting the surface runoff.

A standard condition of the SCS value considers the parameter $\lambda$ to be equal to 0.2 (SCS 1985) and for CN, the greater values means that a lot of the rainfall is transformed into surface runoff and vice versa.

Table 6. CN as a function of LULC and HSGs. (Source: USDA-SCS, 1985)

\begin{tabular}{|l|l|l|l|}
\hline \multirow{2}{*}{ LULC } & CN-II & HSG-C & HSG-D \\
\cline { 2 - 4 } & HSG-B & 83 & 87 \\
\hline Agricultural field & 77 & 100 & 100 \\
\hline Water bodies & 100 & 77 & 83 \\
\hline Degraded forest & 67 & 91 & 94 \\
\hline Rangelands & 86 & & \\
\hline
\end{tabular}


Table 7. Runoff depth suitability class and coverage

\begin{tabular}{|l|l|l|l|l|}
\hline Factor & Runoff depth class & Rate & Classification & Coverage (\%) \\
\hline \multirow{5}{*}{ Runoff $(\mathrm{mm})$} & $136.4-220.7$ & 1 & Unsuitable & 29.5 \\
\cline { 2 - 5 } & $220.7-272.1$ & 2 & Less suitable & 51.7 \\
\cline { 2 - 5 } & $272.1-352.1$ & 3 & Suitable & 11.5 \\
\cline { 2 - 5 } & $352.1-500.6$ & 4 & Very suitable & 7.3 \\
\hline
\end{tabular}
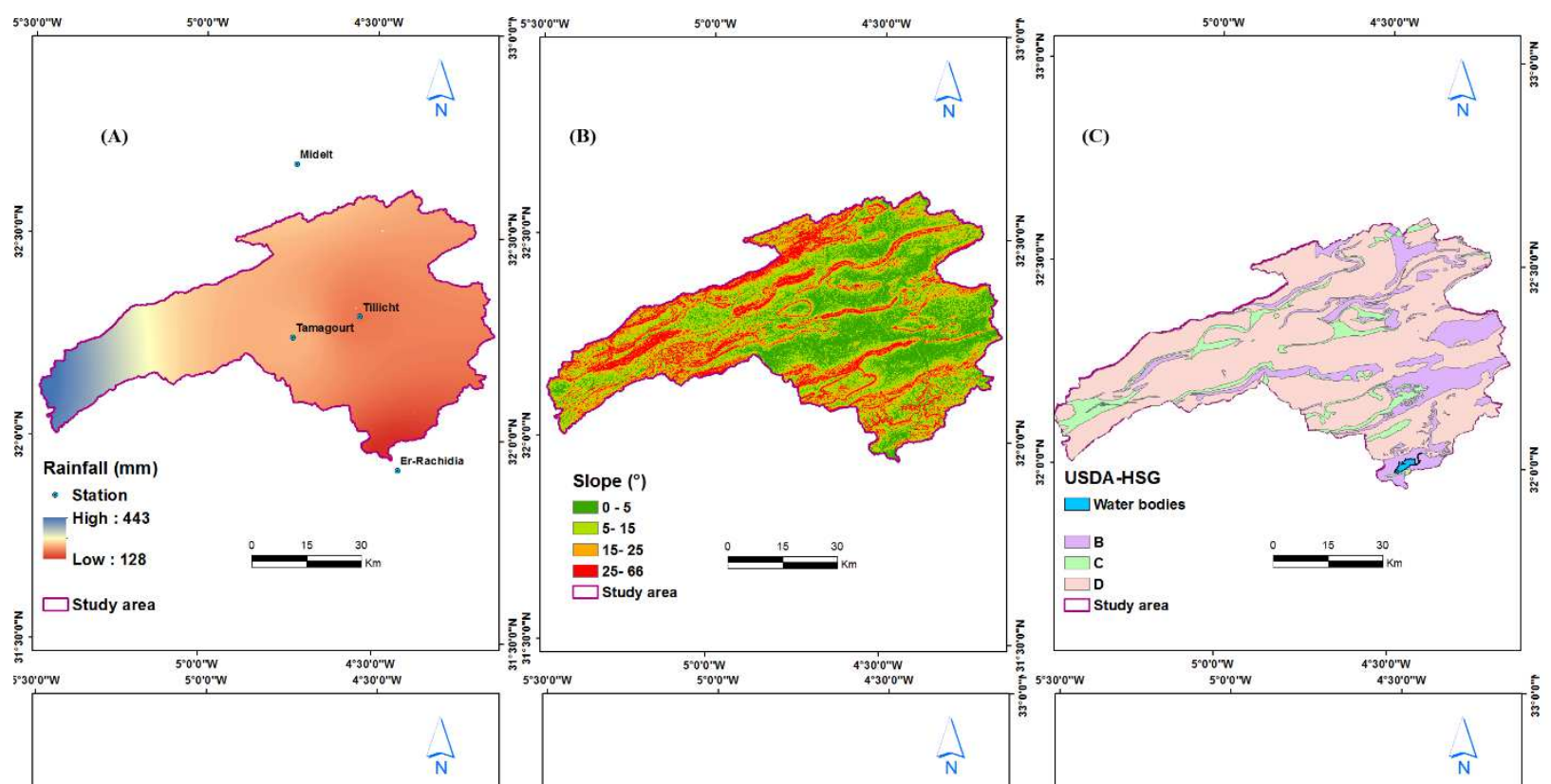

(D)

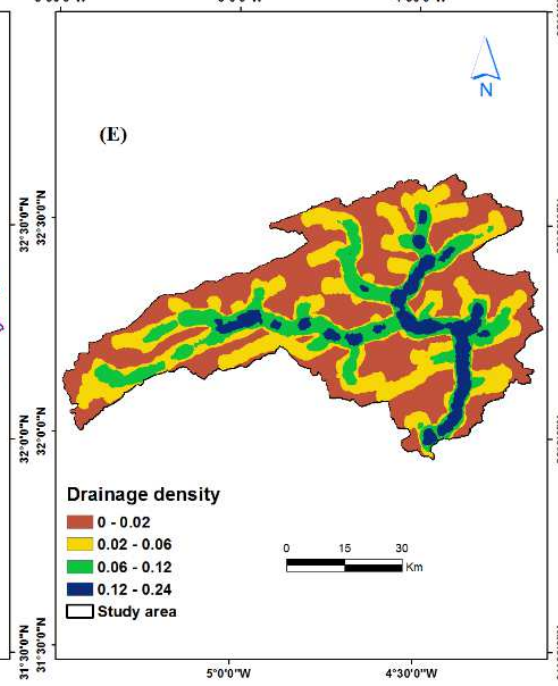

(F)
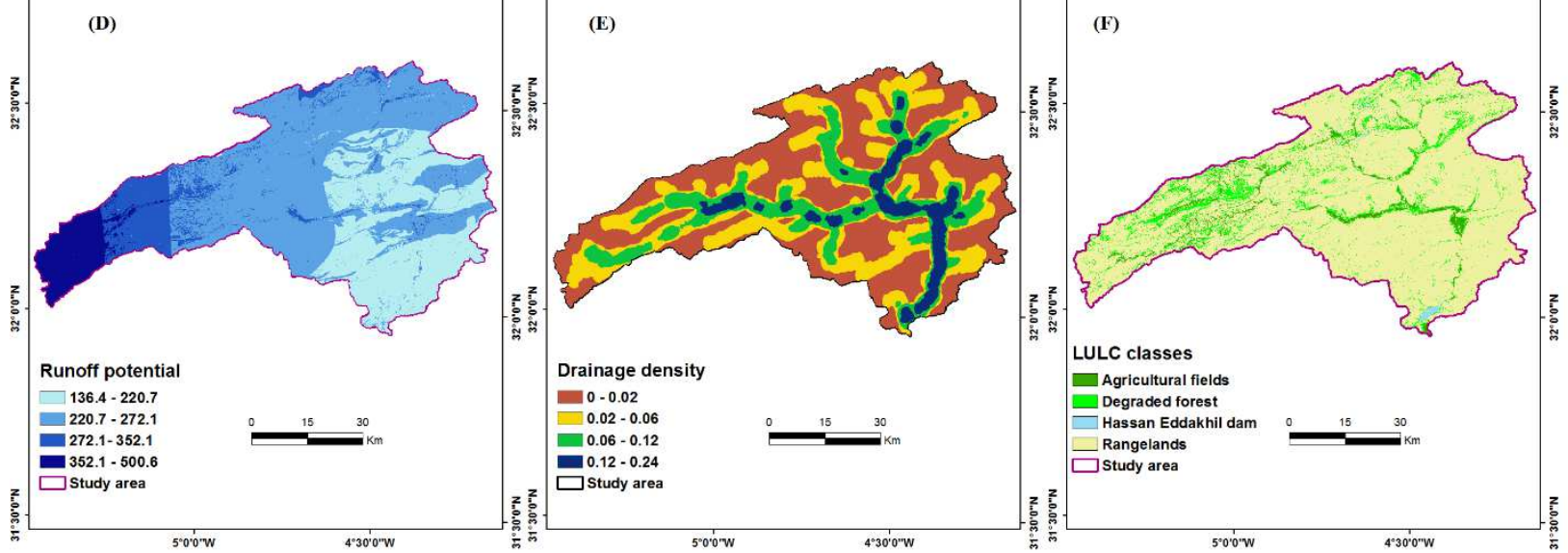

Figure 3 Raster maps used in this study for RWH suitability: (A): Rainfall; (B): Slope; (C): HSG; (D): Runoff; (E): Drainage density; (F): LULC.

\subsection{Fuzzy set theory and fuzzy maps}

In the present study, the well-known Zadeh's fuzzy logic theory has been adopted for giving to each parameter its value. Then, each selected parameter has been converted into a fuzzy raster map by using the linear membership function (LMF) tool of ArcGIS 10.5. In the fuzzy set theory, the member's value 0 means that this member is not a party of a set, whereas the memder's value 1 means that this element is a full 
member of a set (Zadeh 1965). An illustration of fuzzy set is given in the following equation (Mcbratney and Odeh 1997).

$$
A=\{\mathrm{x}, \mu \mathrm{A}(\mathrm{x}) \text { for each } \mathrm{x}\}
$$

Where, $\mu \mathrm{A}$ is the MF (membership of $\mathrm{x}$ in fuzzy set $\mathrm{A}$ ) so that: If $\mathrm{x}$ is not a member of $\mathrm{A}$ then $\mu \mathrm{A}=0$.

If $\mathrm{x}$ is a full member of $\mathrm{A}$ then $\mu \mathrm{A}=1$.

If $x$ belongs in a certain level to $A$ then

$$
0<\mu A(x)<1
$$

As introduced in the equation above, LMF was used for runoff, hydrologic soil group, drainage density and LULC (Feizizadeh and Blaschke 2013).

$$
\mu A(x)=\left\{\begin{array}{cc}
0 & x \leq a \\
\frac{x-a}{b-a} & a<x<b \\
1 & x \geq b
\end{array}\right.
$$

Where $\mathrm{x}$ is the considering parameter and $\mathrm{a}, \mathrm{b}$ are the minimum and maximum values, respectively.

For assessing the slope's effect on RWH suitability, the following LMF was used (Feizizadeh and Blaschke 2013)

$$
\mu A(x)=\left\{\begin{array}{cc}
0 & x \leq a \\
\frac{b-x}{b-a} & a<x<b \\
1 & x \geq b
\end{array}\right.
$$

Where $\mathrm{x}$ is the slope's value and $\mathrm{a}, \mathrm{b}$ are the maximum and minimum values, respectively.

In this work, five criteria for RWH suitability site were used: runoff, slope, drainage density, hydrologic soil group and LULC. Each pixel in Fuzzy map of a factor has its value, and it ranges between the minimum 0 and the maximum 1 .

Table 8. Fuzzy set memberships and control points (min and max) used for RWH site selection.

\begin{tabular}{|l|l|l|l|}
\hline \multirow{2}{*}{ Criteria } & \multicolumn{2}{|l|}{ Control points } & Fuzzy function/membership \\
\cline { 2 - 3 } & $\min$ & $\max$ & \\
\hline Runoff $(\mathrm{mm})$ & 220.7 & 352.1 & Linear, increasing \\
\hline Slope $\left(^{\circ}\right)$ & 30 & 5 & Linear, decreasing \\
\hline Drainage density $(\mathrm{km} / \mathrm{km} 2)$ & 0.02 & 0.12 & Linear, increasing \\
\hline Hydrologic soil group & - & - & Categorical \\
\hline LULC & - & - & Categorical \\
\hline
\end{tabular}

\subsection{Analytic Hierarchy Process (AHP) and criteria's weights}

AHP is a well-known method in multi-criteria decision analysis. In this work, AHP and GIS tools were employed for weighting and integrating the thematic layers. The five factors including runoff, slope, HSG, drainage density and LULC were used in this study. After preparing these layers in the GIS environment, each of them is prioritized to one another layer using expert's judgment. Then, to determine the relative value of the factors, each factor is compared to each other's as a couple and computing the pairwise comparison consistency index until obtaining acceptable results. The following equation shows the consistency ratio computation in AHP method (Saaty 1990). 


$$
C R=\frac{\lambda-n}{n-1}
$$

Where CR is consistency ratio, $\lambda$ is the average value of consistency vector, and $n$ is the number of criteria or factors. Based on this relationship, if CR is less than 0.1, acceptable level of conflict has been paired comparisons, and otherwise, the rates that reflect the judgment are inconsistent (Saaty 1990).

Table 9. AHP criteria pairwise comparison

\begin{tabular}{|l|l|l|l|l|l|l|}
\hline & Runoff & Slope & Dd & ST & LULC & Weight \\
\hline Runoff & 1 & 2 & 3 & 4 & 5 & 0.41 \\
\hline Slope & $1 / 2$ & 1 & 2 & 3 & 4 & 0.26 \\
\hline Dd & $1 / 3$ & $1 / 2$ & 1 & 2 & 3 & 0.16 \\
\hline ST & $1 / 4$ & $1 / 3$ & $1 / 2$ & 1 & 2 & 0.09 \\
\hline LULC & $1 / 5$ & $1 / 4$ & $1 / 3$ & $1 / 2$ & 1 & 0.06 \\
\hline
\end{tabular}

Consistency Ratio (CR) is $2 \%(0.02)$; Consistency Index $(\mathrm{CI})=0.022$ and Random Index $(\mathrm{RI})=1.12$

The CR indicates that the cumulative judgments derived from the pairwise matrix are satisfactory and consistent.

\subsection{Assessment of soil erosion using WaTEM/SEDEM model}

WaTEM/SEDEM is a spatially distributed soil erosion and sediment delivery model that combines the Water and Tillage Erosion Model (WaTEM) and Sediment Delivery Model (SEDEM). It is based on Revised Universal Soil Loss Equation (RUSLE) and a Transport Capacity equation (TC) to predict sediment delivery in drainage network Error! Reference source not found.Verstraeten et al. 2002). WaTEM/SEDEM comprises three modules, the first calculates annual soil loss using the RUSLE model (Renard et al. 1991).

$$
A=R K L S_{2 D} C P
$$

Where $\mathrm{A}$ is the mean annual soil loss $(\mathrm{kg} \mathrm{m}-2 \mathrm{yr}-1), \mathrm{R}$ is a rainfall erosivity factor (MJ mm m-2 $\mathrm{h}-1$ year-1), $\mathrm{K}$ is a soil erodibility factor ( $\mathrm{kg} \mathrm{h} \mathrm{MJ}-1 \mathrm{~mm}-1), \mathrm{C}$ is a dimensionless cover and management factor, $\mathrm{P}$ is a dimensionless erosion control practice factor, $\mathrm{LS}_{2 \mathrm{D}}$ is a slope-length factor (Desmet and Govers 1996)

The second estimates the sediment flux from slopes to the stream network (Van Rompaey et al 2001).

$$
T C=k t c\left(L S_{2 D}-4,1 s^{0,8}\right)
$$

where TC is the annual transport capacity ( $\mathrm{kg} \mathrm{m}-2$ year-1) and $\mathrm{R}, \mathrm{K}$, and LS factors are the same as in RUSLE's equation, $\mathrm{s}$ is the local slope ( $\mathrm{m} \mathrm{m}-1)$ and ktc is a transport capacity parameter $(\mathrm{m})$.

The last module is used for assessing the tillage erosion that represent the net soil flux caused by tillage on a hillslope of infinitesimal length and unit width is proportional to the local slope gradient (Govers et al. 1994):

$$
Q s, t=k t i l l s=-k t i l l d h / d x
$$

Where Qs, $\mathrm{t}$ is the net downslope flux due to tillage translocation ( $\mathrm{kg} \mathrm{m}-1 \mathrm{yr}-1)$, ktill is the tillage transport coefficient (kg m-1 yr-1), $\mathrm{s}$ is the local slope gradient ( $\mathrm{m} \mathrm{m}-1), \mathrm{h}$ is the height at a given point of the hillslope (m) and $\mathrm{x}$ is the horizontal distance (m). 
A spatial distribution map of soil erosion was prepared based on the previous work (Mohamed et al. 2020). For more details on the WaTEM/SEDEM application and validation, we refer to the work of Manaouch et al. 2020 in Ziz upper watershed.

Table 10. Soil erosion suitability class

\begin{tabular}{|l|l|l|l|l|}
\hline Factor & Class & Rate & Classification & Coverage (\%) \\
\hline \multirow{4}{*}{ Soil erosion risk } & Severe & 1 & Unsuitable & 0.2 \\
\cline { 2 - 5 } & High & 2 & Less suitable & 2.5 \\
\cline { 2 - 5 } & Moderate & 3 & Suitable & 21.2 \\
\cline { 2 - 5 } & Slight & 4 & Very suitable & 76.1 \\
\hline
\end{tabular}
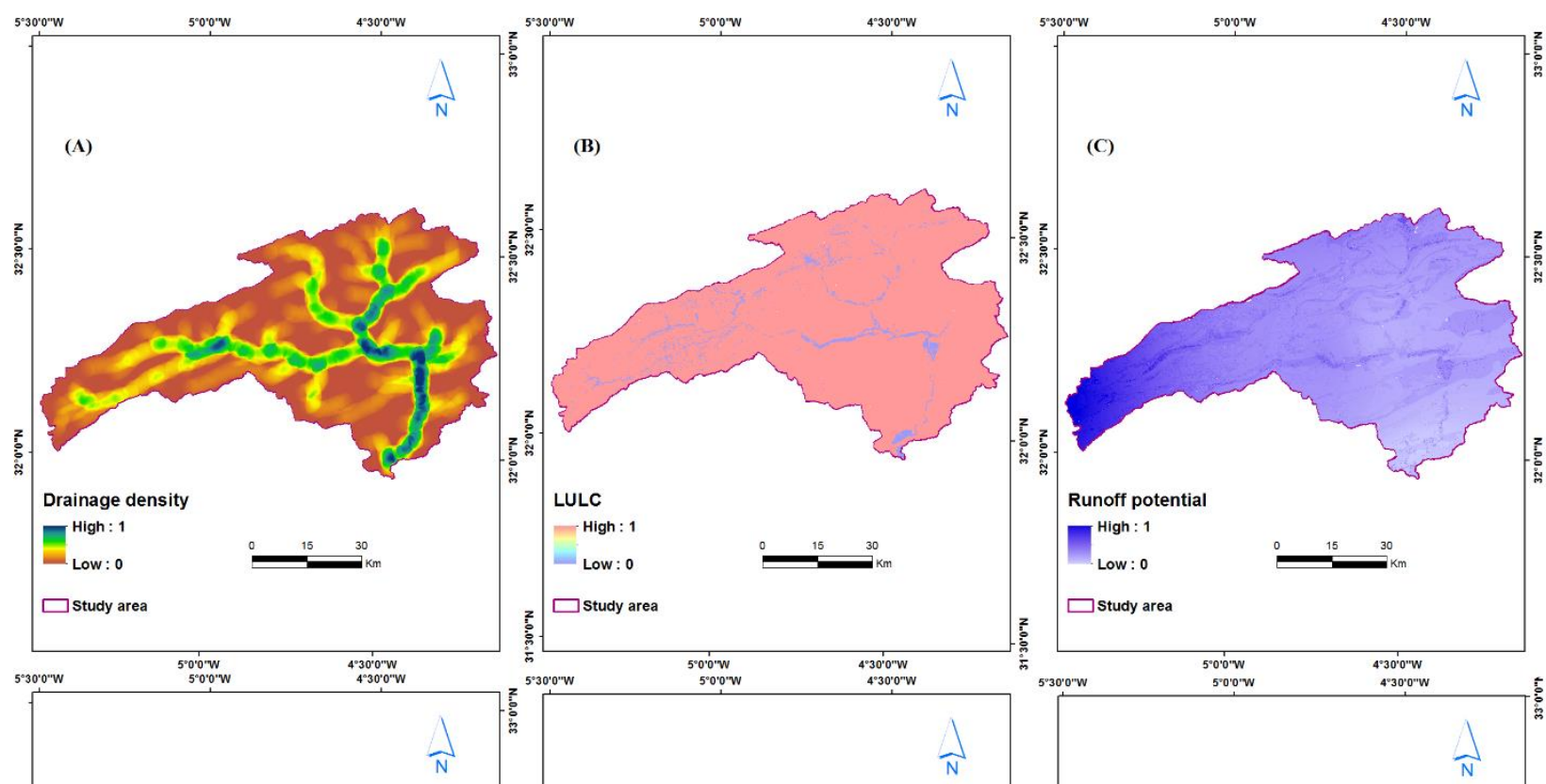

(D)

(E)

(F)
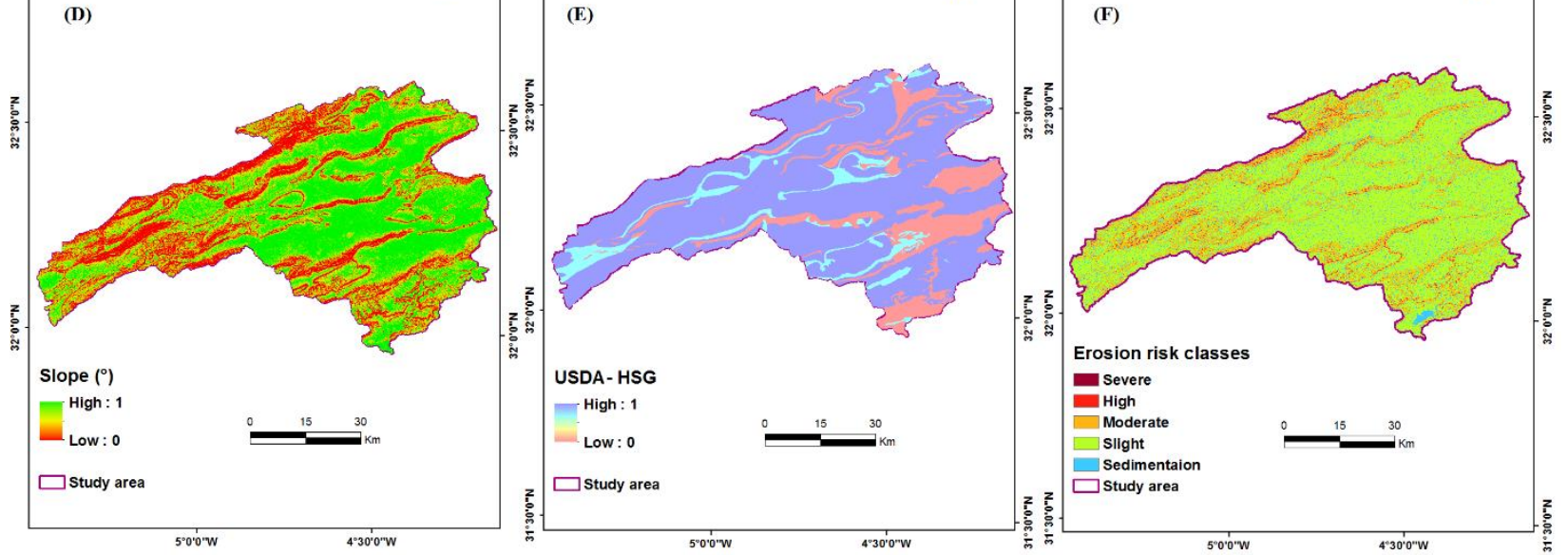

Fig. 4 Fuzzy map of studied area for each RWH suitability parameter: (A): Drainage density; (B): LULC; (C): Runoff; (D): Slope; (E): HSG and (F): Classified soil erosion of WaTEM/SEDEM model.

\subsection{Integration of socio-economic factors in RWH suitability map}


The success of any project is related not only to the technical aspects, but also to how can improve the local community's situation. Many studies illustrated that one of the primary reasons we do not use RWH enough in semi-arid areas is the lack of data on socio-economic contexts. In the present work based on the previous studies and expert judgment's, we are taking into account the distance to the residential farmers and their agricultural fields such as socio-economic criteria affecting the suitability of the installation of RWH sites. Since farmers and rural residents are targeted first, proximity to RWH is an influential parameter in the selection and assessment of suitability of RWH. The distance between residential's home and RWH strictures should be as short as possible. As rural farmers have scattered agricultural fields and each field occupies less than 1 ha and distributed at a distance of approximately 5 to $1000 \mathrm{~m}$ from their residence. Therefore, it is very important that the closer the RWH sites are to the fields, the easier and cheaper the RWH control and surveillance operations will be, especially in mountainous areas where transport is not easy. The distance between sites and fields was assessed using Google Earth images and GIS's buffer tool of ArcGIS 10.5 software.
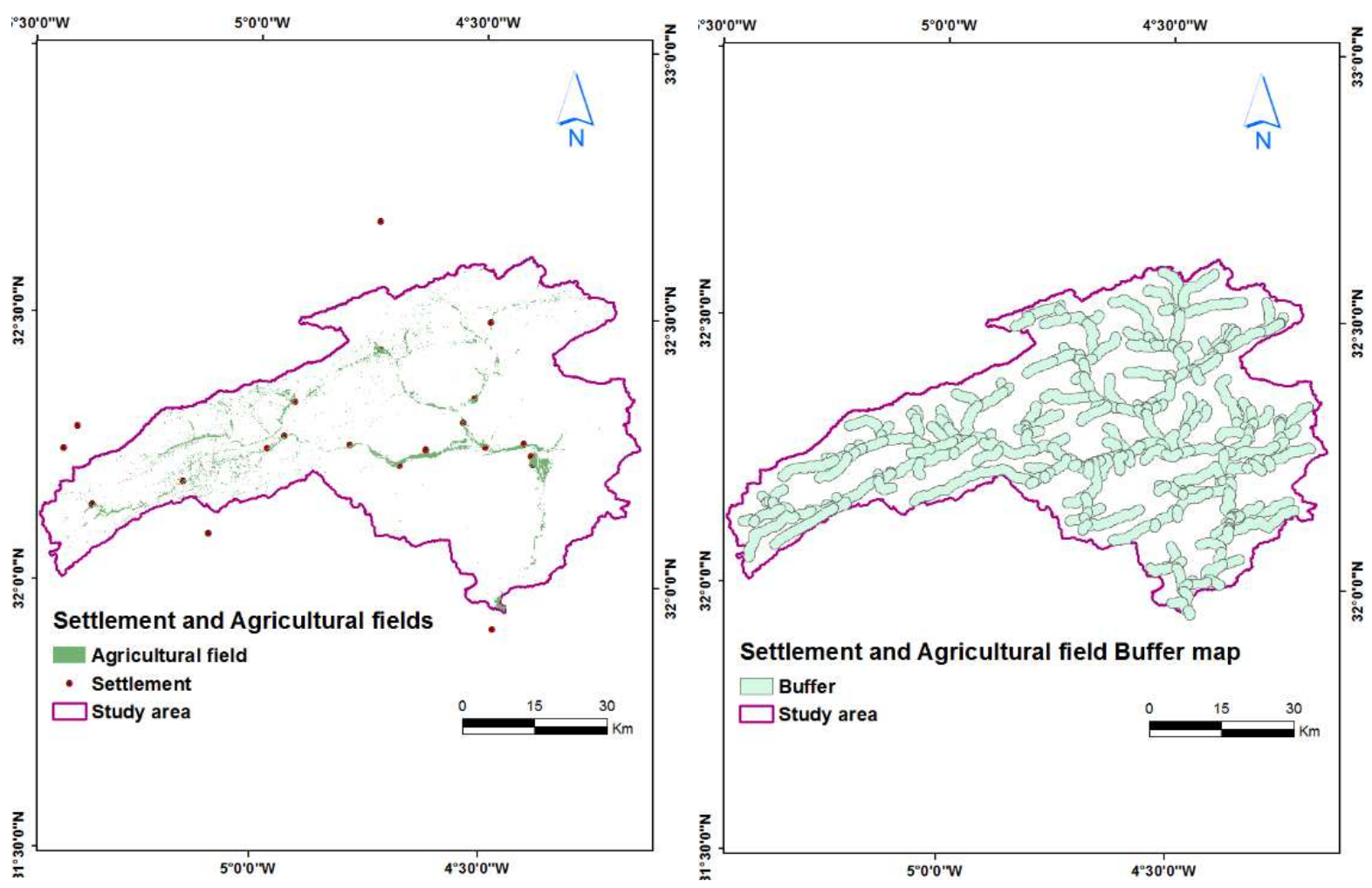

Fig. 5 Distribution of the settlements and agricultural fields (left) and their buffer maps (right).

\section{Results and discussion}

\subsection{Runoff potential}

The Runoff parameter is the most influencing factor for identifying suitable RWH sites. According to the estimated average annual runoffs for different HSG and LULC classes provided in Tables 6 and 7. The yearly runoff average was about $248.5 \mathrm{~mm}$ with a standard deviation of $54.7 \mathrm{~mm}$. The maximum runoff and average annual runoff potential in the western parts were 342.30 and $277.65 \mathrm{~mm}$, respectively. The eastern and southern parts of the Ziz upper watershed are on the periphery of the Tafilalet oasis and the Guir's arid 
watershed, where the potential runoff was the lowest and its average annual was $136 \mathrm{~mm}$. The low runoff yield in these areas was primarily due to lower rainfall. The average annual runoff was also divided into four classes from low to high (Fig. 3D). The very suitable zones of potential runoff accounts for $7.3 \%$ of the study area.

\subsection{Spatial distribution of soil erosion risk}

The risk of soil erosion is narrowly linked to precipitation, soil properties, topography, LULC and human interventions. The transport of soil particles from one place to another can have several impacts, on site such as the decrease of soil productivity. While, the deposition of eroded soil particles can cause imbalances in waterway ecosystems such as deposits in streams and reservoirs which can reduce the quality of their water. The average annual soil loss (A) in the upper Ziz watershed was estimated by exploiting WaTEM/SEDEM model (Fig. 4F). To assess the potential severity of soil loss, the spatial distribution map of soil erosion has been classified into four classes of erosion intensity (Table 10).

According to the classified map produced by WaTEM/SEDEM model, about $76.1 \%$ of the area had a slight soil erosion class, only $0.2 \%$ had a severe soil erosion class and the rest of the area had a moderate to high risk of erosion. The spatial distribution of soil erosion shows that western and northern mountainous areas in the Ziz upper watershed receive an important rainfall amount and are largely occupied by steep slopes, so they have a quite high soil erosion risk. Whilst southern plains and eastern parts have a rather low rainfall and thus a low soil erosion risk.

\subsection{Potential RWH suitability map}

Harvesting rainwater involves collecting, storing and managing rainwater for avoiding water scarcity, and for the maintenance of ecosystems (Studer et al. 2013). In the present study, water deficiency in the study area can be resolute sustainably by improving the collection of rainwater runoff and taking into account soil and water conservation.

According to the two maps of potential runoff and spatial distribution of soil erosion, the study area's ecosystems are largely dominated by very low to feeble runoff and by slight to moderate risk of soil erosion. The potential map of RWH suitability was categorized into five categories i-v: C-i represents high runoff and slight erosion class (extremely suitable), C-ii represents moderate runoff and slight erosion class (very suitable), C-iii represents low runoff and slight erosion class (suitable), C-iv represents very low runoff and slight erosion risk (less suitable) and C-v as unsuitable sites for RWH.

The extremely suitable RWH sites covered an area of $4.3 \%$, while the residual of the study area was classified as suitable and unsuitable for harvesting rainwater. Optimal C-i covered a small area (19072 ha) and sub-optimal Group ii and iii RWH sites covered a larger area, accounting for $63 \%$ of the study area.

In the study area, rangeland is the dominant LULC category, so a high portion of the RWH area was rangeland, and a lower part was agricultural field (Table 11). The western part of the Ziz upper watershed had a large RWH area, the southern and eastern parts of the study area belonging to Tafilalet plain and desert, respectively, had a smaller RWH area and the northern area had small and scattered RWH areas (Fig. $6)$. 

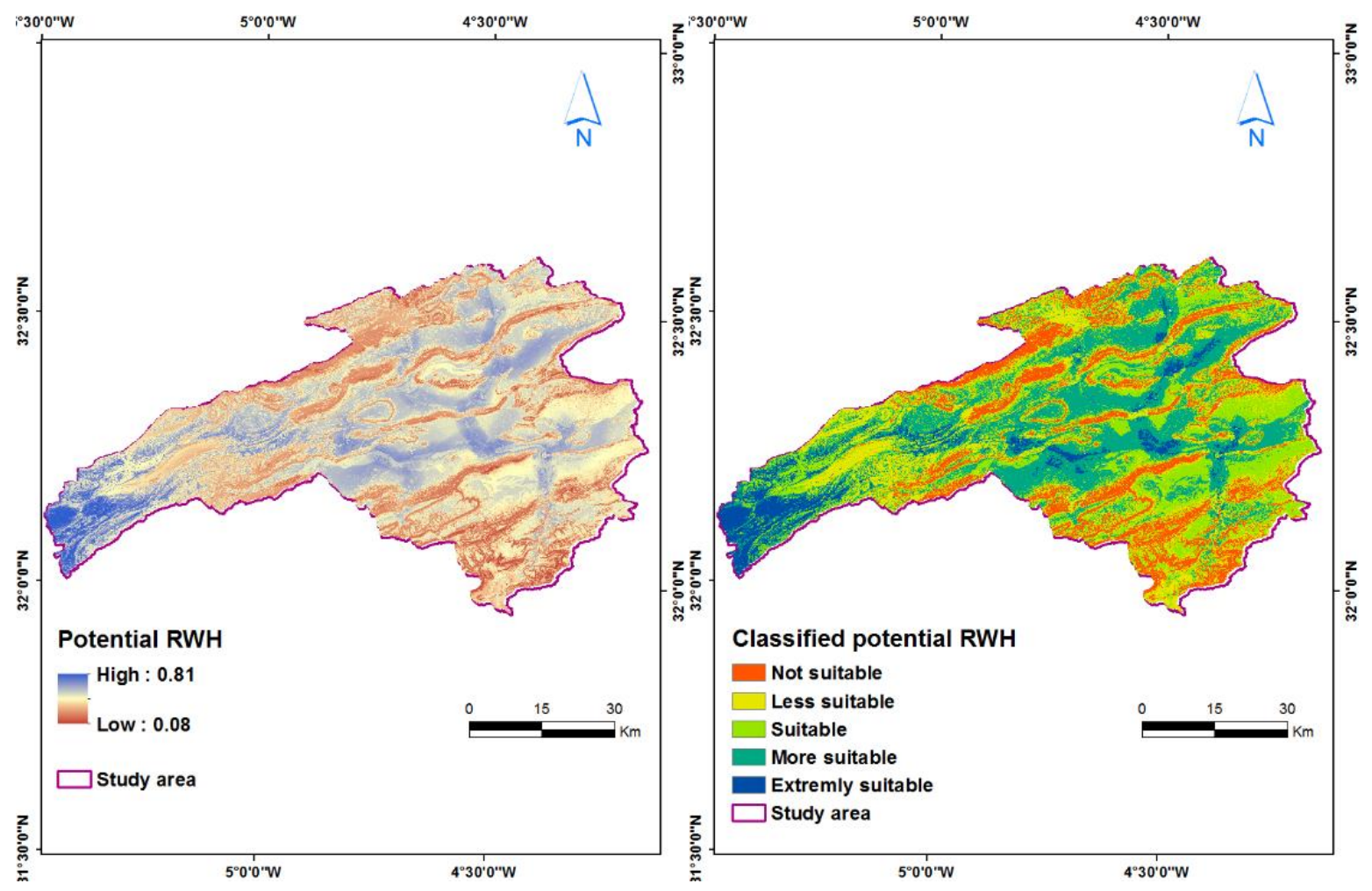

Fig. 6 Potential RWH suitability map (left) and classified potential RWH suitability map (right).

\subsection{Integration of soil erosion and socio-economic factors}

The result of integrating the socio-economic criteria layers of distance to settlement and distance to agricultural field shows that after removing these constraints from the total suitability area, the net area of RWH suitability map decrease from 443,532 ha to 147,864 ha. The excluded areas have 0 value (white color) which means not suitable area and the rest of areas are classed for RWH (Fig. 7). After the constraint's removal from the classified RWH suitability map, the net area coverage for each class has decreased.

Table 11. Potential rainwater harvesting suitability class and coverage

\begin{tabular}{|l|l|l|l|l|l|}
\hline \multirow{4}{*}{ Factor } & \multirow{4}{*}{ Classes } & \multicolumn{4}{l|}{ Potential RWH suitability map } \\
\cline { 3 - 6 } & & Coverage before & \multicolumn{2}{l|}{ Coverage after } \\
\cline { 3 - 6 } & $\%$ & ha & $\%$ & ha \\
\hline \multirow{3}{*}{$\begin{array}{l}\text { RWH } \\
\text { suitability }\end{array}$} & Unsuitable & 10.9 & 48345 & 16.7 & 24693 \\
\cline { 2 - 6 } & Less suitable & 21.6 & 95803 & 19.6 & 28981 \\
\cline { 2 - 6 } & Suitable & 34.5 & 153018 & 26.8 & 39627 \\
\cline { 2 - 6 } & Very suitable & 28.7 & 127294 & 29.9 & 44212 \\
\cline { 2 - 6 } & Extremely suitable & 4.3 & 19072 & 6.9 & 10203 \\
\hline
\end{tabular}




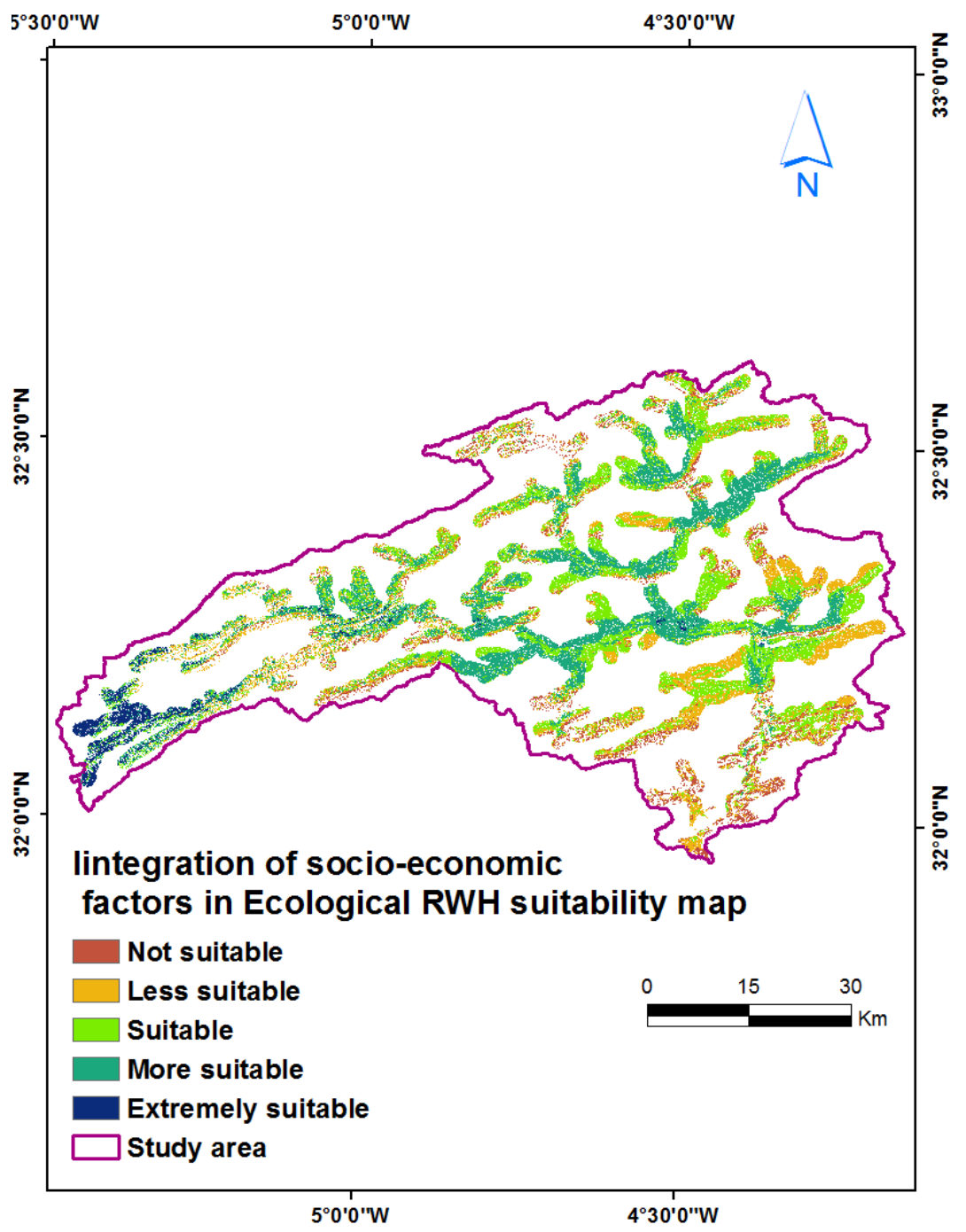

Fig. 7 Potential RWH suitability map with constraints.

\subsection{Validation of the suitability of identified potential RWH sites}

In this study, the prediction accuracy's of FAHP method for identifying RWH sites was evaluated using the receiver operating characteristics (ROC) by comparing the final RWH suitability map with the scattered existing RWH sites in the study area. According to the field visits, 30 current sites were found for harvesting rainwater. They are all earthen dams. These $30 \mathrm{RWH}$ sites were then used to judge the predicted results accuracy of the FAHP model. Next, each pixel value in the resultant RWH map was classified into four groups as unsuitable, less suitable, suitable, more suitable and extremely suitable. Then, using the ArcSDTM tool in ArcGIS 10.5 software, the AUC of the ROC curve was calculated. This AUC represents the accuracy of the model to predict suitable RWH sites (Chen et al. 2016). A good model prediction has AUC values between 0.5 and 1, while values less than 0.5 represent a random fit. The AUC in our study is 0.596 , which corresponds to a prediction accuracy of 59.6\%. This acceptable value of AUC shows that FAHP method was a useful tool for predicting suitable RWH sites in this case study. 


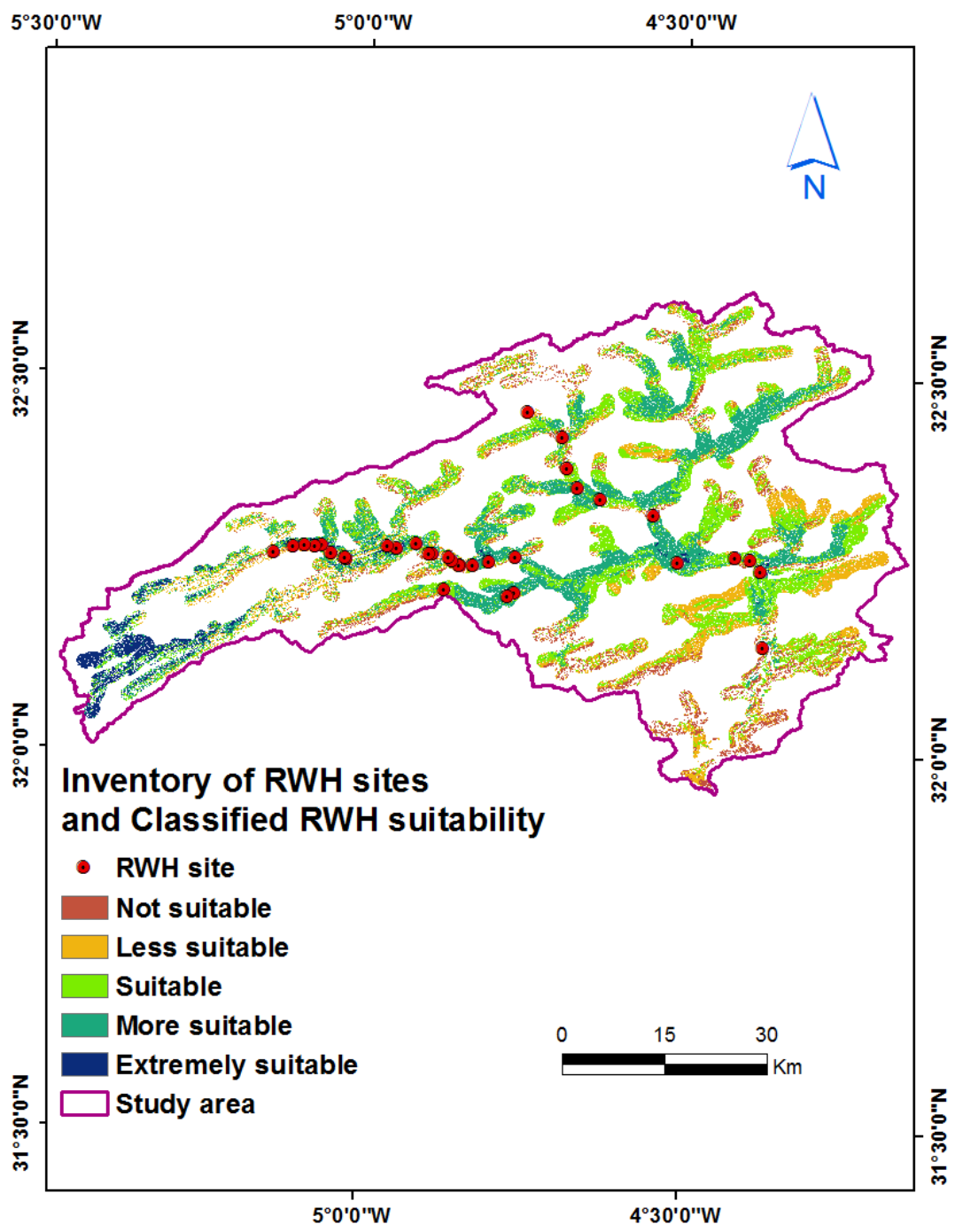

Fig. 8 Classified RWH suitability map with current RWH sites.

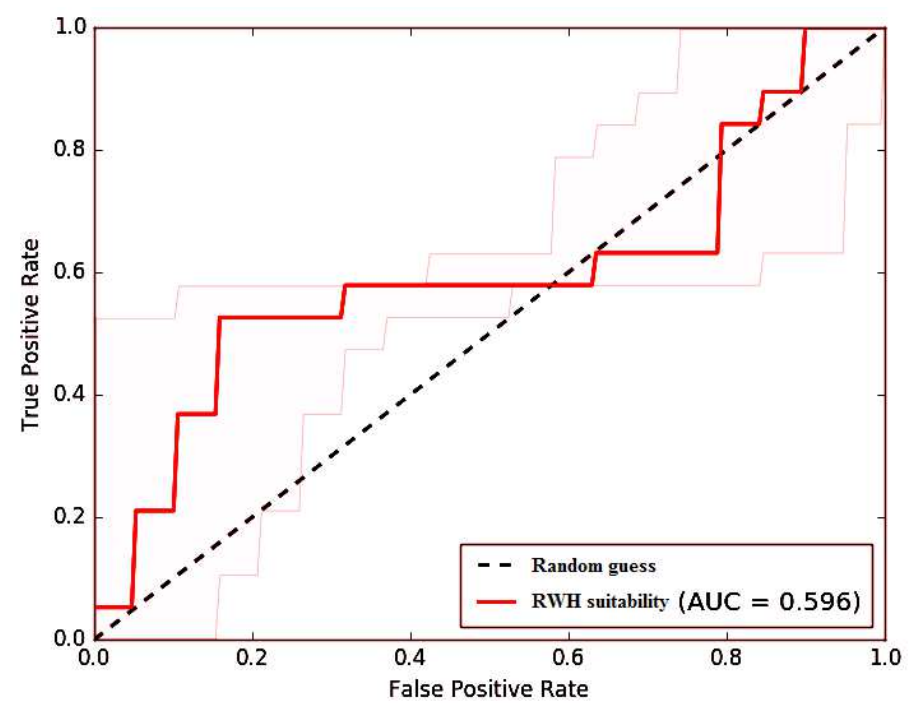

Fig. 9 Prediction rate curve for the potential RWH suitability map produced by FAHP method 


\section{Conclusion}

Arid and semi-arid areas around the world are characterized by dry seasons. For ensuring the water availability, rainwater harvesting is an alternative source. In the present study, Ziz upper watershed was selected as a representative semi-arid region in southeastern Morocco. For identifying ecological suitable sites for harvesting rainwater, the methodology adopted integrates three components: a potential runoff map based on the SCS-CN model with a spatial distribution map of soil erosion based on the WaTEM/SEDEM model and a constraints layers of socio-economic factors. The studied area had very low to low runoff potential and moderate to slight risk of erosion.

The results showed that $6.9 \%$ of the study area was extremely suitable for potential RWH. Optimal RWH sites were scattered in the western parts of the study area. The predicted results verification shows that the accuracy of the method for predicting suitable sites for harvesting rainwater was $59.6 \%$ by comparing the existing RWH sites with the classified map of potential RWH sites. The methodology used in this work demonstrates the utility of integrating a spatially distributed model for soil erosion and GIS based FAHP approach for identifying ecological rainwater harvesting areas in large semi-arid areas. This study has provided a roadmap for siting RWH strictures and alleviating water shortage problems in Ziz upper watershed.

\section{Acknowledgments}

The authors would like to thanks all personal of the hydrologic watershed agency of Ziz-Guir-Ghris (ABHGZR) in Errachidia for providing Data and their kind help. We are grateful to Mr. N. Khan who helped us to validate a predicted result.

\section{References}

ABH-GZR, 2019. Agence du Bassin Hydraulique de Guir-Ziz-Ghris. [Online] Available at: http://www.abhgzr.ma.

Adham A, Riksen M, Ouessar M, Ritsema C (2016) Identification of suitable sites for rainwater harvesting structures in arid and semi-arid regions: A review. International Soil and Water Conservation Research 4:108-120. https://doi.org/10.1016/j.iswcr.2016.03.001

Al-Adamat R (2008) GIS as a decision support system for siting water harvesting ponds in the basalt aquifer/NE Jordan. J Environ Assess Policy Manag 02:189-206 https://doi.org/10.1142/S1464333208003020

Al-Adamat R, Diabat A, Ghada S (2010) Combining GIS with multi-criteria decision making for siting water harvesting ponds in northern Jordan. J Arid Environ 74 :1471-1477. https://doi.org/10.1016/j.jaridenv.2010.07.001

Ajaykumar KK, Sanjay SK, Nagesh NP, Pawar NJ, Sankhua RN (2012) Identifying Potential Rainwater Harvesting Sites of a Semi-arid, Basaltic Region of Western India, Using SCS-CN Method. Water Resour Manage. 26:2537-2554. https://doi.org/10.1007/s11269-012-0031-3

Chen Y, Yu J, \& Khan S (2010) Spatial sensitivity analysis of multi-criteria weights in GIS-based land suitability evaluation. Environmental Modelling \& Software, 25(12):1582-1591.

https://doi.org/10.1016/j.envsoft.2010.06.001 
Chen W, Chai H, Zhao Z, Wang Q, Hong H (2016) Landslide susceptibility mapping based on GIS and support vector machine models for the Qianyang County, China. Environ Earth Sci 75(6):1-13. https://doi.org/10.1007/s12665-015-5093-0

De Winnaar G, Jewitt G, Horan M (2007) A GIS-based approach for identifying potential runoff harvesting sites in the Thukela River basin, South Africa. Phys Chem Earth 32:1058-1067. https://doi.org/10.1016/j.pce.2007.07.009

Desmet PJJ and Govers G (1996) A GIS procedure for automatically calculating the USLE LS factor on topographically complex landscape units. Journal of Soil and Water Conservation 51(5):427-433. https://www.jswconline.org/content/51/5/427/tab-article-info

FAO (20 15) Available online: http://www.fao.org/ag/agp/greenercities/en/whyuph/

FAO. Land and Water Digital Media Series, 26. Training Course on RWH (CD-ROM). Planning of Water Harvesting Schemes, Unit 22; Food and Agriculture Organization: Rome, Italy, 2003.

Feizizadeh B, Blaschke T (2013) GIS-multicriteria decision analysis for landslide susceptibility mapping: comparing three methods for the Urmia lake basin, Iran. Nat Hazards 65(3):2105-2128. https://doi.org/10.1007/s11069-012-0463-3

Ghani MW, Arshad M, Shabbir A, Mehmood N \& Ahmad I (2013). Investigation of potential water harvesting sites at Potohar using modeling approach. Pakistan Journal of Agricultural Sciences 50(4).

Govers G, Vandaele K, Desmet P, Poesen J and Bunte K (1994) The role of tillage in soil redistribution on hillslopes. European Journal of Soil Science 45(4):469-478. https://doi.org/10.1111/j.1365-

2389.1994.tb00532.x

He CS (2003) Integration of geographic information systems and simulation model for watershed management. Environ Model Softw 18:809-813. https://doi.org/10.1016/S1364-8152(03)00080-X

Horton RE (1945) Erosional development of streams and their drainage basins; hydrophysical approach to quantitative morphology. Geol. Soc. Am. Bull 56:275-370. https://doi.org/10.1130/0016 7606(1945)56[275:EDOSAT]2.0.CO;2

Isioye OA, Shebe MW, Momoh U, Bako CN (2012) A multi criteria decision support system (MDSS) for identifying rainwater harvesting site(s) in Zaria, Kaduna state, Nigeria. Int. J. Adv. Sci. Eng. Tech. Res. $1: 53-71$.

Kaposztasova D, Vranayova Z, Markovic G, Purcz P (2014) Rainwater Harvesting, Risk Assessment and Utilization in Kosicecity. Slovakia. Procedia Eng 89:1500-1506, doi: 10.1016/j.proeng.2014.11.439.

Luxon N, Pius C (2013) Validation of the rainfall-runoff SCS-CN model in a catchment with limited measured data in Zimbabwe. International Journal of Water Resources and Environmental Engineering 5: 295-303. https://agris.fao.org/agris-search/search.do?recordID=QL2018000932

Mahmoud SH, Alazba AA (2014) The potential of in situ rainwater harvesting in arid regions: developing a methodology to identify suitable areas using GIS-based decision support system. Arab. J. Geosci. 72:3429-3442. https://doi.org/10.1007/s12517-014-1535-3 
Manaouch M, Anis Z, Fenjiro I (2020) Assessment of Soil Erosion by RUSLE Model using Remote Sensing and GIS - A case study of Ziz Upper Basin Southeast Morocco. Forum geografic 19(2):131-142 DOI:10.5775/fg.2020.013.d

Mekdaschi SR, Liniger H (2013) Water harvesting: guidelines to good practice. Centre for Development and Environment (CDE), Bern; Rainwater Harvesting Implementation Network (RAIN), Amsterdam; MetaMeta, Wageningen (p. 210) Rome: The International Fund for Agricultural Development (IFAD)

Mohamed M, Anis Z and Imed F (2020) Regional-scale modeling of water erosion and sediment yield in a semi-arid context: A case study of Ziz upper watershed in south-eastern Morocco. GEOIT4W-2020: Proceedings of the 4th Edition of International Conference on GeoIT and Water Resources 2020, Al Hoceima, Morocco, March 11 -12, 2020, DOI: 10.1145/3399205.3399209

MycBratney AB, Odeh IOA (1997) Application of fuzzy sets in soil science: fuzzy logic, fuzzy measurements and fuzzy decisions. Geoderma 77:85-113. https://doi.org/10.1016/S0016-7061(97)00017-7

Napoli M, Cecchi S, Orlandini S, Zanchi CA (2014) Determining potential rainwater harvesting sites using a continuous runoff potential accounting procedure and GIS techniques in central Italy. Agricultural Water Management 141:55-65. https://doi.org/10.1016/j.agwat.2014.04.012

Pandey A, Sahu AK (2002) Generation of curve number using remote sensing and geographic information system. Water Resources, Map India Conference 6 to 8 February, New Delhi, India.

PNABV, 2014. Plan National d'Aménagement des Bassins Versants : Étude d'aménagement du bassin versant d'Assif Melloul, Agence du Bassin Hydraulique de l'Oum Er-Rbia. [Online] Available at: www.eauxetforets.gov.ma

Prinz D, Oweis T and Oberle A (1998) Water Harvesting for Dry Land Agriculture Developing a Methodology Based on Remote Sensing and GIS. accessed online at www.ubka.uni karlsruhe.de/indexervvv/1998/bauverm/4-25k

Ramakrishnan D, Durga Rao KHV, Tiwari KC (2008) Delineation of potential sites for water harvesting structures through remote sensing and GIS techniques: a case study of Kali watershed, Gujarat, India. Geocarto International 23: 95-108. https://doi.org/10.1080/10106040701417246

Rejani R, Rao KV, Srinivasa R et al. (2017) Identification of potential rainwater-harvesting sites for the sustainable management of a semi-arid watershed. Irrig. and Drain. 66:227-237.

https://doi.org/10.1002/ird.2101

Renard KG, Foster GR, Weesies GA and Porter JP (1991) RUSLE-revised universal soil loss equation. Journal of Soil and Water Conservation 46(1):30-33. https://www.jswconline.org/content/46/1/30.short

Saaty TL (1980) The analytical hierarchy process, 350. New York: McGraw Hill.

https://doi.org/10.1002/atr.5670290109

SCS. Hydrology. In National Engineering Handbook; United States Department of Agriculture, Soil Conservation Service, US Government Printing Office: Washington, DC, USA, 1985.

SCS, U (1972) National engineering handbook. Hydrology Section 4.

Studer RM, Liniger H (2013) Water harvesting: guidelines to good practice. Nato Asi. 22:137-168

United Nations (2014) Available online: http://www.un.org/waterforlifedecade/scarcity.shtml 
USDA NRCS. Chapter 7 -Hydrologic Soil Groups in: NRCS-National Engineering Handbook (NEH), Part 630 -Hydrology. USDA NRCS, Washington, DC, 2009, 7.1-7.5.

Van Rompaey AJJ, Verstraeten G, Van Oost K, Govers G and Poesen J (2001) Modelling mean annual sediment yield using a distributed approach. Earth Surface Processes and Landforms 26(11):1221 1236. https://doi.org/10.1002/esp.275

Verstraeten G, Van Oost K, Van Rompaey A, Poesen J and Govers G (2002) Evaluating an integrated approach to catchment management to reduce soil loss and sediment pollution through modelling. Soil Use and Management 18(4):386-394. https://doi.org/10.1111/j.1475-2743.2002.tb00257.x

Zadeh LA (1965) Fuzzy sets. Information and Control 8(3):338-353.

https://doi.org/10.1142/9789814261302 0021 